about the normal over a limited patch of country lying to the north-west of the Caspian, and over the whole of Asia to the east of a line drawn through Ceylon, the Upper Ganges, and Lake Baikal, this latter area of high pressure extending as far south over Australia as Adelaide. Another area of bigh pressure spread from Central America eastwards across the West Indies, the north of South America, and the Atlantic to Africa.

In accordance with this distribution of pressure temperature was from one to two degrees above the normal in the United States, except in the north-east, where it fell to the average in the New England States, and fell still further to $I^{\mathrm{c}} 6$ below it at St. John's, Newfoundland. Under the influence of the low pressure around Ireland the Weather Map shows a prevalence of strong breezes from the Atlantic over Western, Central, and Eastern Europe as far as Kiev, and over the whole of this wide region tempcrature was above the normal, most notably so over Great Britain and the south of Norway, the mean at Mandal being $4^{\circ} \cdot 2$ above the average.

Over England these Atlantic breezes were southwesterly, but in Scotland easterly. In England the month was one of the rainiest Augusts on record, and in the east of Scotland the rains were also unusually heavy. On the other hand, what invariably happens when the weather in the east of Scotland is characterised by rain and east winds, the weather of the West Highlands was dry and bright.

The comparatively insignificant region of higher pressure to the north-west of the Caspian, taken in connection with the markedly low pressure in Western and Central Siberia, exerted a striking influence on the weather of that region, since, owing to the northerly winds, which necessarily set in with stronger force than usual, temperatures fell to from two to three degrees below the normal from the Irtish to the Dnicper. On the other hand, over Northern $\Lambda$ sia, to the east of long. $75^{\circ}$, tem. peratures above the average prevailed, the excess at Irkutsk being $3^{\circ} \mathrm{O}$. In Victoria, pressure being lower on the coast than in the interior, northerly winds set in, and under their influence the temperature of the colony rose generally to $I^{\circ} 5$ above the normal. In New Zealand pressure was not only very low, but diminished greatly from west to cast over the islands, and owing to the strong westerly winds which accompanied this distribution of the pressure, the temperature fell generally $2 .{ }^{\circ} 5$ below the average of this winter month.

\section{THE IRON AND STEEL INSTITUTE}

FOLLOWING close upon the Institution of Mechanical Engincers came the meeting of the Iron and Steel Institute. The bill of fare of the younger association was certainly longer, and will probably be found not less interesting, than that of its elder colleague. It contained eleven papers on subjects of practical importance connected with the nature and manufacture of iron and steel. All of these papers were valuable, five of them especially so, and they prove beyond a doubt that the Iron and Steel Institute is doing immense service to metallurgical science in collecting and systematising practical information, and in affording opportunities for the discussion of theoretical opinions.

It was naturally to be expected that the recent meeting would furnish some information as to the practical working and commercial success of the Thomas-Gilchrist process of producing Bessemer steel from inferior brands of pig-iron, and especialiy from those descriptions, like Cleveland pig, which are rich in the very deleterious ingredient, phosphorus. At the last spring meeting of the Institute this process was little more than an idea, but it was clearly scen that if it could be rendered a commercial success its influence on the future of the North-Eastern iron district of this country could not fail to be enormous.
Accordingly we are not surprised to find two papers on this subject, one by Messrs. Holland and Cooper, of Sheffield, entitled "On the Manufacture of Bessemer Steel and Ingot Iron from Phosphoric Pig," and the other by. Mr. R. Pink, of the Horde Works, Westphalia, "On the Dephosphorisation of Iron in the Bessemer Converter." From these two papers we learn the most recent results of British and German experience, and it must be deemed a matter of great congratulation that in both countries much good progress seems to have been made in the practical working of the new process.

The difficulties encountered were only such as are always encountered in the introduction of any new method. The first of these minor troubles experienced in Sheffield was to find out the rigbt moment when to stop blowing. "It seemed doubtful whether it would be practicable (having no definite point at which we could safely stop blowing, corresponding to the drop of the carbon flame in the ordinary process) to burn out the whole of the phosphorus regularly, without sometimes carrying the process too far, and thereby oxygenating the charge. Aad this, as all steel makers will agree, is very apt to give trouble." However, by taking samples of the metal from the converter during the "after-blow," and testing them, it was found practicable to stop the process at the right time, and to remove the phosphorus in a very satisfactory manner. Here, however, a new difficulty arose. The time lost while the samples were being taken cnable the slag and metal to accumulatc at the "nose" of the converter, and partially choke the aperture, thus causing great inconvenience and loss of time in removing the obstruction. By reducing the area of the aperture, and thus tetaining the beat better in the converter, and by limng the nose with fire-brick, this difficulty was partially got over, but the accumulations of slag still continued at the junction of the fire-brick and bassic lining of the converter. Increased experience, however, soon enabled the Sheffield manufacturers to complete the blowing by timing with a watch, without the testing of samples, and as no time was given for the accumulation of slag, no further trouble was experienced. How completely the timing system answered may be judged from the following extract from Messrs. Holland and Cooper's paper :-" In the week ending April 17, when not a single sample was taken during the operation, except in the case of the experimental blow 748, the average amount of phosphorus contained in 36 blows, all of which were analysed, was '056 per cent., the highest being "IOI por cent., and the lowest "org per cent." The composition of this quality of steel has been in other respects very regular, the analyses and results of a test piece 2 inches long and 533 inches in diameter being as follows:-

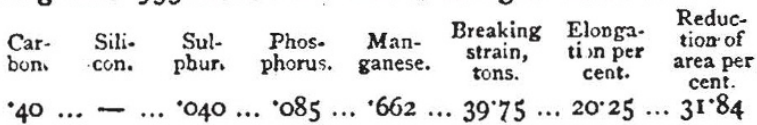

It has been found that since sampling has been dispensed with, that the wear of the lining of the converter is very uniform. As many as 630 tons of steel have been produced from one lining, without any repairs excepting a new fire-clay brick-lining for the nose; and 270 tons more were got from the same lining after renewing the front or blowing side, and putting in a new nose. This absence of difficulty about the renewal of the plant, coupled with the excellent quality of the metal produced, show that the process must now be pronounced a commercial success.

The experiences of the Sheffield manufacturers werc amply borne out by the results arrived at at Hœrde. Mr. Pink says in the beginning of his paper: "Without doubt we are on the verge of making from the very worst classes of pig iron a most reliable and remarkably cheap steel," and this assertion is amply borne out by the results of chemical analysis and mechanical testing which he 
publishes. "In the softer qualities for plates, wire, \&c., it is at times astonishing what results are obtained. With 37 to 40 kilogrammes of actual breaking weight, as much as 70 per cent., and in some cases even 75 per cent. of contraction has been reached. At the same time this ingot iron can take very high heats, forging and rolling without a flaw. The production of this especial quality is so simple, the cheapness of the raw material, the certainty in working, its softness, and its ductility, all point to its driving at no very distant date puddled iron plates out of the market. For wire even of the smallest gauges it has been declared better than that drawn from billets puddled from charcoal pig."

This is an extremely good result to have attained in the short space of less than a year, and gives good ground for the hope of further improvement in the future. The manufacturers do not appear as yet to have quite succeeded in producing a hard steel by this process.

The remainder of Mr. Pink's paper contains an account of very similar difficulties experienced and overcome to those described by Messrs. Holland and Cooper.

A paper of considerable practical interest was read by Mr. Henry Simon, C.E., of Manchester, "On an improved System for the Utilisation of Bye-Products in the Manufacture of Coke." It is well known that in the manufacture of gas for lighting purposes the sale of the byeproducts, such as tar and ammoniacal liquor, which are obtained during the distillation of the coal, is one of the chief sources of profit. In the manufacture of coke it has hitherto been-the practice in this country to allow the tar and ammoniacal liquor to run to waste. Such a course not only causes waste, but increases the great nuisance of coke ovens to the neighbourhood in which they are planted. The extent of the waste may be inferred when it is stated that at Manchester the gas-works obtain $38 s$. per ton for tar, and from $20 s$. to $25 \mathrm{~s}$. per ton for their ammoniacal liquor; and it has been found at Bessèges, in France, where the bye-products are saved, that every ton of coke obtained gives nearly 3 cwts. of ammoniacal liquor, and $72 \frac{1}{2}$ lbs. of tar, worth together, at Manchester prices, about $4 s$. $6 d$. per ton of coke produced.

In this country over $7,000,000$ tons of coke a year are produced for the manufacture of pig-iron alone, the value of the bye-products of which is about $1,350,000 l$., a sum which is annually lost to the nation. The demand for the ammoniacal liquor, both for agricultural purposes and for the manufacture of soda, is practically unlimited. As an instance of the truth of this statement it may be mentioned that one firm of soda-manufacturers, viz., Messrs. Solway, have contracted for the whole production of the Bessèges Works, and transport it 300 miles by rail to their factory near Nancy.

By the new method of production nearly the whole of the noxious effect of the old "beehive" coking ovens is done away with. So great are these ill-effects that in the words of the Royal Commission on noxious vapours, which sat in 1877, "all vegetation near coke ovens, conducted on the older methods, suffers severely. The growth of trees is checked or destroyed, fences are killed. crops of every description are injured, cattle suffer, and upon many occasions the effect of the vapours emitted by coke ovens is terrible." In the counties of Durham and Northumberland alone 6,000,000 tons of coal are annually co'zed, and in the process give off $2,000,000$ tons of vapours, which consist in great part of the valuable tars and nitrogenous compounds which might so easily be saved. The quantity of sulphurous acids which escape into the atmosphere every year in these districts is estimated to be about 70,000 tons.

In the process described by Mr. Simon "the coal is rapidly carbonised by subjecting a comparatively thin layer of it to a high temperature in a closed and retortlike vessel, and whilst in the beehive ovens the volatile products are burned inside, we burn them around the out- side of this retort-like vessel, and only after they are deprived of the tar and ammoniacal liquor." Besides saving these products, the heat of the hot gases is utilised greatly for the production of steam. At Bessèges about 45 pounds of water is evaporated into steam of $4 \frac{1}{2}$ atmospheres pressure per hour and per ton of coal coked; and it is said that under more favourable circumstances 59 pounds might be evaporated. The remainder of the paper contains a technical description of the new apparatus, the advantages of which are stated to be as follows :--

"I. Greater yield of coke by about Io per cent.

" 2 . Greater purity of coke.

"3. A yield of about $4 s$. worth of useful bye-products per ton of coke.

"4. An almost entire absence of smoke or noxious vapours.

" 5 . In comparison with any other existing system of coke ovens, equal facilities for utilising the heat, and a reduced cost for repairs."

Messrs. John Parry and Alexander Tucker read a joint paper "On the Application of the Spectroscope to the Analysis of Iron and Steel." They commenced by noticing that the analysis of iron and steel is usually summed up in percentages of iron, manganese, carbon, silicon, sulphur, and phosphorus, and perhaps copper, nickel, and cobalt, and suggested that other elements might also be at work, and that we ought not to remain satisfied with percentages of the above substances till we have proved the absence of others. It has, however, been found extremely difficult to prove the absence of the rarer elements, partly because the traces of these latter are apt to accompany the large mass of iron throughout the chemical processes. Under these circumstances it was thought that the spectroscope, which has done so much good work in other departments of chemistry, might be usefully employet.

"Theoretically a well-focussed photographed spectrum of a steel should be an unerring index to its composition; this is partly true in practice, but it is not in our experience absolutely so." "We have found the spectra of pure iron, Bessemer steel, tool steel, chrome steel, Siemens' steel, and pig iron to be decidedly different, and the differences would be characteristic, but they failed to show the presence of bodies which further experiment proved to exist." "There are several reasons why this should be the case.

"I. The number of lines due to iron is so great (IOOI3o) that they overlap in the small spectra the lines due to otber bodies, and our apparatus does not readily allow of images larger than one or two inches being taken.

" 2 . The intensity of light due to the traces of bodies may not be sufficient to record lines on the plate.

" 3 . Because of the variation in the volatility of the elements, and therefore the necessity of variation in the intensity of the spark."

The authors therefore thought it important either to separate the iron or considerably lower its percentage, and the solution of this problem was their principal aim. The results of their experiments have led them to believe that as a rule the quantity of iron is much over-estimated. In confirmation of this opinion they also quote the fact that iron and steel are capable of absorbing twenty times their volume of hydrogen, a quantity which is always omitted in ordinary analysis, "which is probably due to the fact that a steel saturated with hydrogen must be less liable to oxidation in the heating furnace than one containing little or none. In order to eliminate the iron a method of digestion with various solvents was adopted. By this process much larger quantities can be operated on at a time than by the ordinary methods of precipitation. As much as 7,000 grains of Bessemer steel were dissolved in aqua regia. The solution was evaporated and heated in a paraffin bath till the acids were driven off. Ammonia 
was then poured on and allowed to act under pressure for several hours. It was then filtered off and evaporated to dryness with nitric acid, so as to decompose any ammonia salts. The residue was then treated in three different ways, and the spectrum photographed in each case.

I. With excess of hydrochloric acid. 2. Water was added to the iron and boiled with it. 3. Acetic acid was added and boiled with the iron, some of which was dissolved, and the solution was therefore nearly neutralised with ammonia and boiled. Photographs were then taken of the spectra of the iron thus precipitated and the filtrate from it. The following is a summary of the results obtained :-

\begin{tabular}{|c|c|c|c|c|c|}
\hline $\begin{array}{l}\text { Ammonia. } \\
\text { Nickel }\end{array}$ & & & $\begin{array}{l}\text { Water. } \\
\text { Calciumm }\end{array}$ & & $\begin{array}{l}\text { Acetic Acid. } \\
\text { Antimony }\end{array}$ \\
\hline Cadmium & $\ldots$ & $\ldots$ & Manganese & $\ldots$ & Lead \\
\hline Calcium & $\ldots$ & $\ldots$ & Copper . & $\ldots$ & Aluminium \\
\hline Manganese & & $\ldots$ & & & Copper \\
\hline Copper . & ... & $\ldots$ & & & $\begin{array}{l}\text { Calcium } \\
\text { Manganese }\end{array}$ \\
\hline
\end{tabular}

"The above experiments were made with $7^{\circ}$ coils and dense prisms of $60^{\circ}$ and $75^{\circ}$, with object-glasses of quartz. By using an electro-dynamic machine a greater dispersion might be used, and the length of the image increased. We think that it would then be found that the bodies which we have detected by indirect means would appear in the spectrum of the original metal."

In addition to the above Mr. Wrightson read a second paper "On some physical changes occurring in Iron and Steel at High Temperatures," which was a continuation of a paper read by him at the Liverpool meeting last year. Mr. Ackerman, of Stockbolm, contributed a very lengthy memoir "On Hardening Iron and Steel ; its Causes and Effects." There were also five other papers on subjects of importance, chiefly to those technically interested in the manufacture of iron and steel.

In conclusion the Institute must be congratulated not only on the importance and number of the papers produced, but also on the fact that it has succeeded in obtaining contributions from three foreign countries, viz., Germany, Russia, and Norway, a circumstance which will no doubt give to the proceedings of the association an international importance.

\section{NOTES}

Mr. W. Chandler Roberts, F.R.S., Chemist of the Mint, has been appointed to the Lectureship of Metallurgy in the Royal School of Mines, rendered vacant by the resignation of Dr. Percy, F.R.S. Mr. Roberts will continue to hold his appointment at the Mint. Mr. Richard Smith, hitherto Assistant Metallurgist, has been appointed Instructor in Assaying.

THE following foreign men of science have recently (May 6) been elected Foreign Members of the Linnean Society :-M. C. J. de Maximowicz, Director of the Imperial Museum and Herbarium, St. Petersburg, author of many important memoirs on systematic botany; l)r. Edward Strasburger, Professor of Botany in the University of Jena, well hnown for his morphological and physiological researches among various groups of plants ; and Prof. Elias Metschnikoff, Director of the Embryological and Zoological Institute, Odessa, whose investigations on the structure and development of the lower marine invertebrata are highly valued.

THE Municipality of Rome has just erected on the promenade of the Pincio a statue in honour of Father Secchi. The statue represents the great astronomer in the attire of a member of the Company of Jesus.

UNDER their present government the French are multiplying the statues erected to their men of science by means of public subscription. Not less than three new schemes are on foot for that purpose in several parts of the country. A committee has been established at Montpellier for Auguste Comte; another at Blois, in honour of Denis Papin, a rival of the Marquis of Worcester, who, according to the French notion, invented the steam-engine; and a third at Bar-le Duc, on behalf of François Cugnot, an engineer born in the vicinity of that city, who in 1770 constructed a road-locomotive. This rudimentary steam-engine, which is exhibited just now at the Conservatoire des Arts et Métiers, was tried officially but unsuccessfully in the arsenal of Paris more than a century ago.

Dr. Nils Johann ANDERsson, the celebrated Swedish botanist and traveller, as the Gardener's Chronicle learns from the Botanisches Centralblatt, died after long suffering on March 27 at Stockholm. Andersson was born on February 20, 1821 , studied at Upsal, graduated as Doctor of Philosophy in 1845 , and resided at the University as Assistant Professor of Botany. Afterwards he took part in the expedition of the frigate Eugenie round the world, $1851-1853$, the result of which he published in several treatises which were translated into various foreign languages. In 1855 he became Demonstrator of Botany at Lund, and in the following year was appointed permanent Professor of Botany, Director of the Bergianska 'schen Garten and $\mathrm{Su}$ erintendent of the botanical division of the Royal Museum. There he worked with great success till the beginning of 1879 . From here Andersson undertook numerous journeys in the cause of science to Lapland, Norway, Germany, France, England, \&c. He also acquired scientific renown through his various treatises, books of travel, and text-books.

Prof. Silvestri, of Catania, reports as follows concerning the renewed activity of Etna, to which we referred last week :"The eruption issues from the western side of the mountain, precis $=l y$ the part which separates the central crater from the eruptive craters of last year. The situation indicated represents the principal part of the ravine which was then formed and remained opened, and which, beginning at the recent eruptive craters, finally crosses the great crater. This ravine, in which are many crater-caverns which opened last May but remained inactive, is now the scene of the present activity, limited as yet to a simple eruption of steam and ashes, such as has frequently taken place during the past months at the summit of the mountain. To-day (April 28), while the sky is cloudless, one sees from Catania the summit of Etna enveloped in clouds which, scattered by a rather strong north-east wind, have no resemblance to eruptive clouds, though they are formed by the steam issuing from the mountain. The eruption of mud at Paterno to the south still continues, and on certain days in some of the craters increases in energy, ejecting as abundant mud as during the first days after the appearance of the phenomena."

ON Tuesday evening a paper on the botanical enterprise of the empire was read to the Colonial Institute in St. James's Hall by Mr. Thiselton Dyer, assistant director of Kew Gardens. The lecturer gave a history of botanical gardens, which date from the middle of the sixteenth century, when Alfonso d'Este, Duke of Ferrara, the patron of Tasso, set the fashion of making collections of foreign plants and flowers. The earliest public botanic garden was founded by Cosmo de' Medici in 1544 for the University of Pisa. The following year one was founded at Padua. In France the earliest botanic garden was founded at Montpellier towards the end of the sixteenth century, and in Germany that of Giessen was established in 1614 , and in the Low

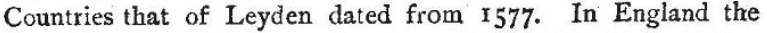
Royal Garden at Hampton Court was founded by Queen Elizabeth, and supported by Charles II. and George III. Those which followed and still remain were Oxford, founded in 1632 ; Chelsea, in 1673 ; and Edinburgh, in 1680 . The origin of Kew as a 